\title{
Bセッション 12233456
}

\section{高齢者の薬物療法 : \\ ポリファーマシーとフレイルヘの配慮}

秋下 雅弘

Key words 薬物有害事象，老年症候群，サルコペニア，マルチモビディティ (multimorbidity)

\section{はじめに}

高齢者の薬物療法を困難にする要因として, 有効性のエビデンスがそしい一方で，薬物有害 事象のリスクが高い，つまり，益と害のバラン スの判断が難しい点が挙げられる。薬物有害事 象の二大要因は, 薬物動態の加齔変化とポリ ファーマシー (polypharmacy) であるが, 量の 調節に対する意識はかなり高まったものの, ポ リファーマシーについては未だ改善がみられな い.しかし, ポリファーマシーには, 有害事象 以外にも多くの問題が関連するため, 一定の歯 止めが必要である. 本稿では, ポリファーマシー とフレイル（frailty）を中心に，高齢者に対す る薬物療法の注意点を解説する.

\section{1. ポリファーマシーとは}

文字どおりに解䣋すれば，ポリファーマシー =多剂服用（多剂併用，多剂処方）であり，研 究上の取り扱いでも一定数以上の薬剤を服用し
ている状況をポリファーマシーとするのが一般 的である. 海外文献では 5 種類以上, 時に 4 種 類以上をポリファーマシーとして取り扱ってい るものが多い, しかし, 最近の考えでは, 多剤 服用のなかでも害をなすものを特にポリファー マシーと呼び，両者を使い分けるようになって きた。

2018 年 5 月に発表された厚生労働省による 「高齢者の医薬品適正使用の指針 (総論編)」1)で は, ポリファーマシーは, 単に服用する薬浏数 が多いことではなく, 薬剤数増加に関連して薬 物有害事象のリスク増加, 服薬過誤, 服薬アド ヒアランス低下等の問題につながる状態である とし, 何剤からポリファーマシーとするかにつ いて厳密な定義はなく, 患者の病態, 生活, 環 境により適正処方も変化するとしている.

例えば，3種類でも相互作用や服用管理で問 題が起きれば, ポリファーマシーに該当するか もしれないし, 10 種類でも適切に管理され, 病 状のコントロールも本人のQOL（quality of life） も良好であれば，ポリファーマシーに該当する 


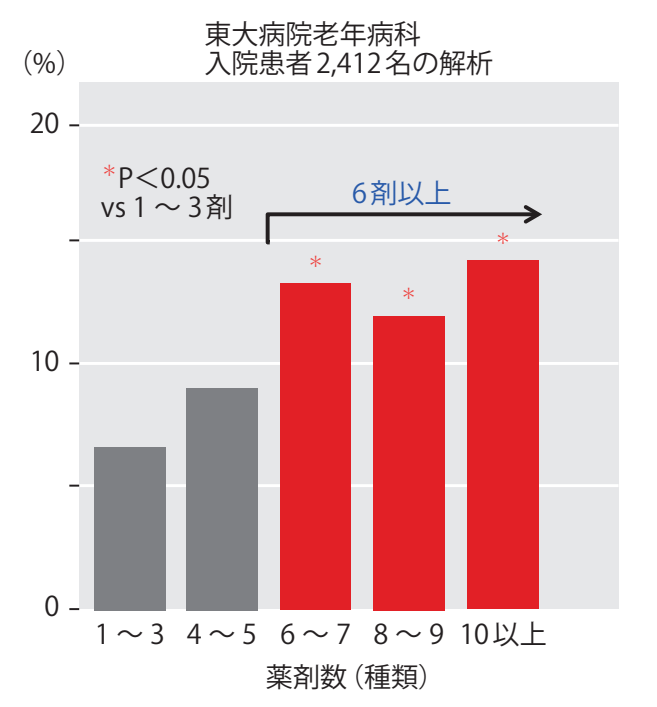

図 1 薬剤数と薬物有害事象の発生 (文献2より引用)

とは言えない。このように, 一律の剂数及び種 類数のみに着目するのではなく, 安全性の確保 等からみた処方内容の適正化が何より重要であ る，そうは言っても，6種類以上で高齢者の薬 物有害事象のリスクが増加する一方 (図 1) ${ }^{2)}$, 75 歳以上の約 4 割が 5 種類以上, 約 $1 / 4$ が 7 種 類以上の内服薬を 1 つの薬局から調剤されてい る現状1)を考えると，高齢者はポリファーマ シー状態にある場合が多いと考えられる.

注意したいのは, ポリファーマシーの定義で いう害とは，今みられる有害事象だけではな く, 今後起きる可能性の高い有害事象 (potential harm）を特に念頭に置いている点である.つま り, 薬物有害事象やその他の薬物関連問題を事 前に回避するという趣旨が込められている。 従って，対応も必ずしもすぐに行う必要はな く, 患者本人を含む関係者と十分協議したうえ で次回以降の処方に反映するように，段階的に アクションを起こすことが望ましい.

\section{2. 薬棛起因性老年症候群としてのフレイル}

高齢者の薬物有害事象は, アレルギー症状や 薬剤性腎障害・肝障害としてよりも, 老年症候 群として現れることが多く, 薬凨起因性老年症 候群と呼ばれる。ふらつき・転倒, 抑うつ, 記 憶障害, せん妄, 食欲低下, 便秘ならびに排尿 障害・尿失禁等が代表的であり（表）, 薬剤とは 関係なく高齢者によくみられる症状であるた め, 薬剤性と気付きにくく, 発見が遅れること が特徴である。

フレイルは, 身体的, 精神心理的ならびに社 会的側面から構成される多面的概念であるが, 老年症候群のうち, 記憶障害とせん妄, 抑うつ が精神心理的フレイルに関わる症候であり, ふ らつき・転倒, 抑うつ, 食欲低下ならびに便秘 は身体的フレイルに関わる. ふらつき・転倒は 身体的フレイル及びサルコペニア（sarcopenia， 加齢性筋肉減少症）の代表的症候であり，抑う つは廃用性筋萎縮と食欲低下を介して, 便秘は 食欲低下を介して, 食欲低下は栄養摂取不足に より, 身体的フレイルとサルコペニアの原因と なる。

表に示した薬剤がフレイルの原因となる薬剤 であり，その多くは「高齢者の安全な薬物療法 ガイドライン $2015 」^{2)}$ にあ「特に慎重な投与 を要する薬物のリスト」に含まれている，同リ ストの詳細は, 日本老年医学会のホームページ にも掲載されているので参照いただきたい.

身体的フレイルと精神心理的フレイルの双方 に関わる代表的薬剤として, ベンゾジアゼピン 系睡眠薬・抗不安薬と抗コリン薬が挙げられ る.ベンゾジアゼピンには, 中枢神経抑制によ る認知機能低下作用と筋弛緩作用がある. 抗コ リン薬は神経伝達物質であるアセチルコリンに 拮抗するため，神経系に有害な作用を有するこ とは自明である。これらの有害事象は, 臨床的 にも数多くの研究で示されている. 特に抗コリ ン薬はポリファーマシーとの関連が深く, 多数 
表＼cjkstart薬剤起因性老年症候群と主な原因薬剤（文献1より引用）

\begin{tabular}{|c|c|}
\hline 症候 & 薬剂 \\
\hline ふらつき・転倒 & $\begin{array}{l}\text { 降圧薬 (特に中枢性降圧薬， } a \text { 遮断薬， } \beta \text { 遮断薬)，睡眠薬，抗不安薬，抗うつ薬，てんかん治療 } \\
\text { 薬，抗精神病薬 (フェノチアジン系)，パーキンソン病治療薬（抗コリン薬)，抗ヒスタミン薬 (H2 } \\
\text { 受容体拮抗薬含む)，メマンチン }\end{array}$ \\
\hline 記憶障害 & 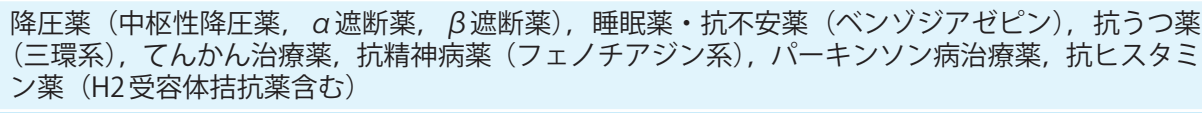 \\
\hline せん妄 & 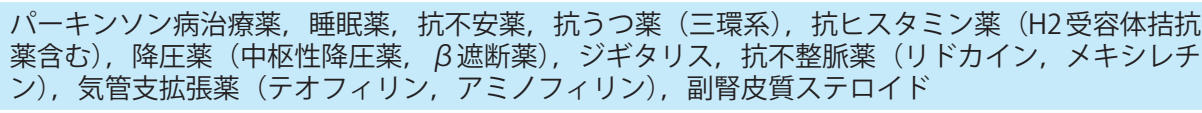 \\
\hline 抑うつ & $\begin{array}{l}\text { 中枢性降圧薬， } \beta \text { 遮断薬，抗ヒスタミン薬（H2受容体拮抗薬含む），抗精神病薬，抗甲状腺薬，副 } \\
\text { 腎皮質ステロイド }\end{array}$ \\
\hline 食欲低下 & $\begin{array}{l}\text { 非ステロイド性抗炎症薬 (NSAID)，アスピリン，緩下剂，抗不安薬，抗精神病薬，パーキンソン病 } \\
\text { 治療薬 (抗コリン薬)，選択的セロトニン再取り込み阻害薬 (SSRI)，コリンエステラーゼ阻害薬， } \\
\text { ビスホスホネート，ビグアナイド }\end{array}$ \\
\hline 便秘 & 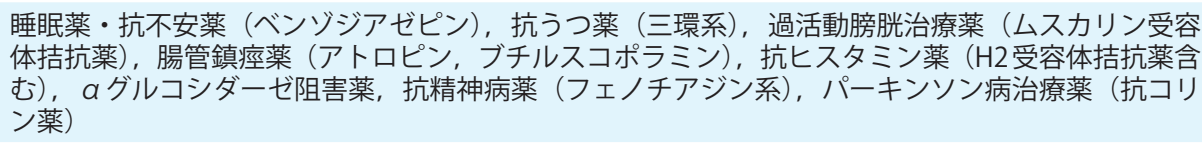 \\
\hline 排尿障害・尿 & 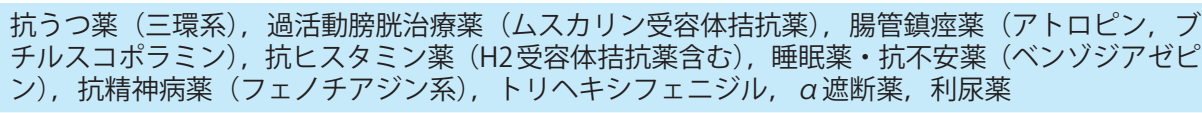 \\
\hline
\end{tabular}

NSAID : non-steroidal anti-inflammatory drug, SSRI : selective serotonin reuptake inhibitor

の併存疾患でそれぞれの疾患に対して抗コリン 薬が処方される結果，抗コリン作用の力価が高 くなると, 認知症あるいはAlzheimer病の発症リ スクが高まることが示されている31.

このような臨床的エビデンスに基づいて「高 齢者の安全な薬物療法ガイドライン2015」で は, 高齢の患者に使用すると認知機能障害（せ ん妄・認知機能低下・認知症）を来たす可能性 のある薬物には何があるか? という CQ (clinical question, クリニカルクエスチョン) に対して,

・抗コリン作用をもつ薬物 [フェノチアジン 系などの抗精神病薬, 三環系抗うつ薬, パーキ ンソン病治療薬（抗コリン薬）, 第一世代ヒスタ ミン $\mathrm{H}_{1}$ 受容体拮抗薬, ヒスタミン $\mathrm{H}_{2}$ 受容体拮抗 薬, 頻尿治療薬など]は, 認知機能障害と関連 するため減量または中止を検討する. (エビデン スの質：中, 推奨度：強）

- 向精神薬 (抗不安薬, 抗精神病薬, 睡眠薬, 抗うつ薬）は抗コリン作用と同様, 認知機能障
害と関連する可能性がある.（エビデンスの質： 低, 推奨度：弱）

・特に, ベンゾジアゼピン系睡眠薬・抗不安 薬, オキシブチニンは, せん妄・認知機能低下・ 認知症発症に関連することが強く示されてい る.（エビデンスの質：高，推奨度：強） と記載されている.

以上のように, 薬剤が標的臓器以外にも作用 をもたらす可能性を常に考慮し, 新たな症候が みられる場合には，まず有害事象を念頭に置い た問診と検索を進めることが重要である.

\section{3. フレイル予防のための生活習慣病管理}

糖尿病や高血圧等の生活習慣病はフレイルの 危険因子であるため, 少なくとも中高年期はそ の厳密な管理に努めることが重要である。しか し, 高齢期, 特に 75 歳以上で生理的予備能が低 下した状態になると, 厳密な管理に伴う有害事 


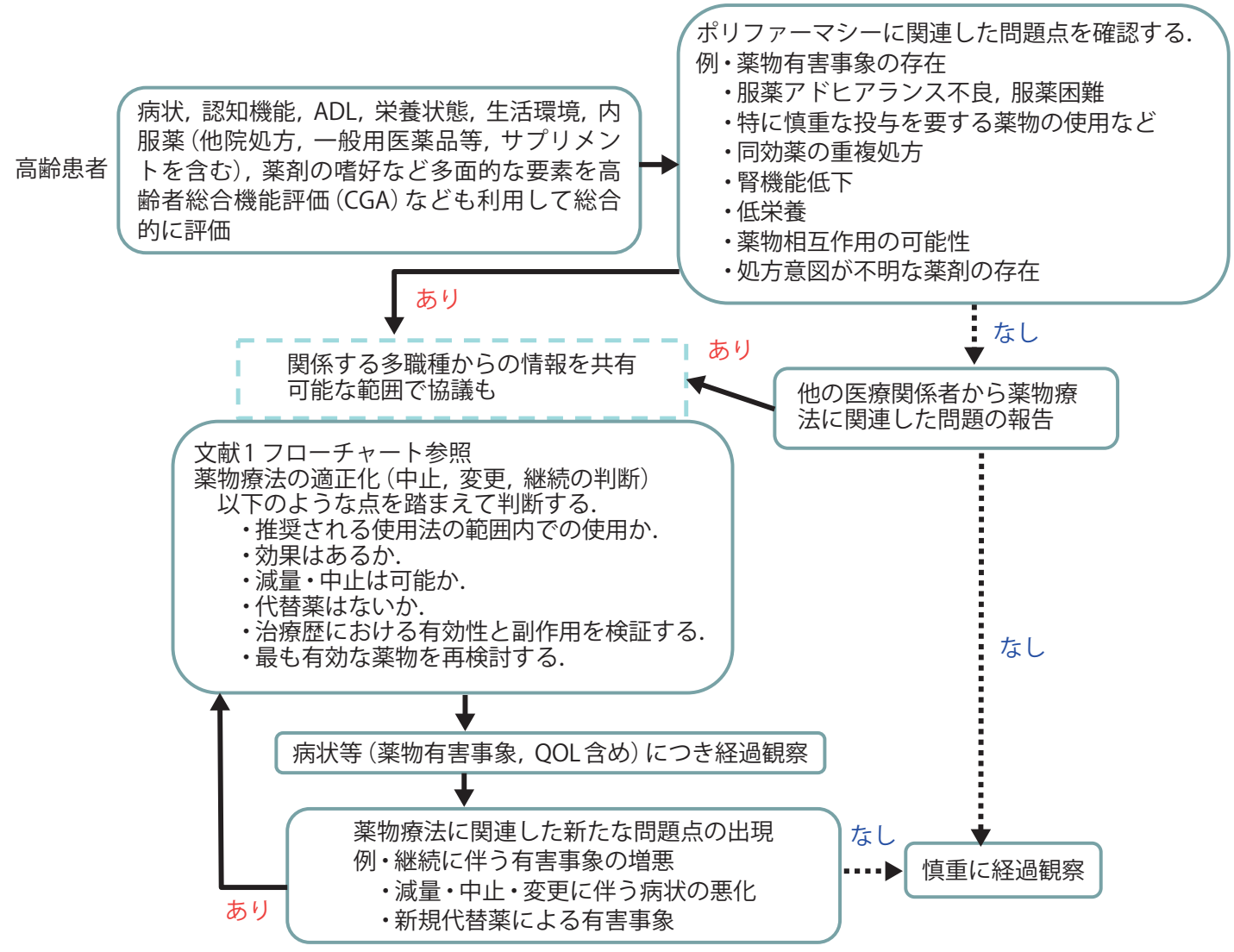

図2 処方見直しのプロセス (文献1より)

象がむしろフレイル，さらに要介護を招くこと に注意が必要である.

高齢者糖尿病では, 重症低血糖を起こすと, その後, 認知症を発症するリスクが上昇し, さ らに，低血糖の頻度に応じてリスクが増加する といった報告が相次いだ4). その結果, 高齢者 糖尿病では, 低血糖を避けることを優先すべき という考えが世界的なコンセンサスとなり，そ のためのガイドライン作成が進んだ. 日本でも 高齢者糖尿病の治療向上のための日本糖尿病学 会と日本老年医学会の合同委員会から「高齢者 糖尿病の血糖コントロール目標2016」が発表さ れ, 認知機能とADL (activities of daily living)に応 じて管理目標を緩くすることが推奨されている. 高血圧についても，過降圧による有害事象の
リスクを回避することが必要である.イタリア のメモリークリニックで行われた認知症と軽度 認知障害を対象とした追跡研究では, 降圧薬を 使用中で診察室の収縮期血圧が $125 \mathrm{mmHg}$ 以下 の場合，それ以上に管理されていたグループに 比べて, 明らかにその後の認知機能の低下が顕 著であったことが示されている5)。 また, 降圧 は転倒のリスクも伴うため, フレイルな患者で は特に注意が必要である。

\section{4. ポリファーマシー見直しの基本的な考え方}

図2のフローチャートに処方見直しのプロセ スを示す。多病（multimorbidity）と複数診療 科・医療機関の受診がポリファーマシーの最大 
の要因であるため, 疾患単位の足し算的処方で はポリファーマシーから免れない. 全ての併存 疾患, 生活機能, 生活環境ならびに意思・嗜好 等に基づき, 薬剤間の優先順位も考慮して取捨 選択することが求められる。 その際には, 高齢 者総合的機能評価 (comprehensive geriatric assessment：CGA）も取り入れるとよい.CGAに は要素毎にツールがあり, 詳細は日本老年医学 会ホームページの「高齢者診療における打役立 ちッール」等を参照いただきたい.

現在までに系統的なポリファーマシー改善の ための減薬手順は確立されていない。むしろ, 機械的に薬剤を減らすことはかえって病状を悪 化させる懸念がある. 薬物療法の効果を判定す るうえでは, 日常生活の変化等の情報を踏ま え, 薬剤の変更や代替薬について検討を行うこ とが有効である. 服用回数の減少や配合剤の導 入等服薬錠数の減少も服薬アドヒアランスの改 善には有効である，薬唷を中止する場合には, 病状の急激な悪化や有害事象のリスク上昇の可 能性に留意し, 少しずつ慎重に行う。さらに, 治療法の変更により対象疾患の増悪が認められ ないか, 過剩な治療効果が出ていないか, また, 変更した代替薬による有害事象が起きていない か等, 慎重な経過観察を欠かしてはならない.
ポリファーマシー対策には, 多職種協働と患 者・家族の理解も重要である. 特に薬の専門家 である薬剤師, 服用状況や症状の把握には看謢 師, 非薬物的対応については管理栄養士や理学 療法士, 作業療法士の役割が期待される. 一般 向けにも「多すぎる薬と副作用」というパンフ レット（日本老年医学会ホームページ）が用意 されており，啓発に利用いただきたい。

\section{おわりに}

フレイルには有効な薬物療法が存在しない一 方で, 薬物はしばしばフレイルあるいはその増 悪の原因となる．疾患を治療するために使用さ れる薬物であるが, ポリファーマシーによる有 害事象のリスクも含めて, その害が益を上回る ケースが高齢者では多くなることを念頭に置 き, 常に薬物療法を見直す必要があることを強 調したい.

著者のCOI (conflicts of interest) 開示 : 秋下雅弘；講演 料 (MSD，第一三共，大日本住友製薬，武田薬品工業）, 研究費・助成金 (日本イーライリリー)，寄附金 (アス テラス製薬，MSD，小野薬品工業，サノフィ，第一三 共，武田薬品工業，田辺三菱製薬，中外製薬，ツムラ， 日本ベーリンガーインゲルハイム, ノバルティスファー マ，バイエル薬品，ファイザー，持田製薬）

\section{文献}

1）厚生労働省：高齢者の医薬品適正使用の指針（総論編）。2018年 5 月. https://www.mhlw.go.jp/content/11121000/kourei-tekisei_web.pdf

2）日本老年医学会, 日本医療研究開発機構研究費・高齢者の薬物治療の安全性に関する研究研究班編: 高齢者の安全 な薬物療法ガイドライン 2015. 日本老年医学会, 東京, 2015 .

3) Gray SL, et al : Cumulative use of strong anticholinergics and incident dementia : a prospective cohort study. JAMA Intern Med $175:$ 401-407, 2015.

4) Whitmer RA, et al : Hypoglycemic episodes and risk of dementia in older patients with type 2 diabetes mellitus. JAMA 301 : 1565-1572, 2009.

5) Mossello E, et al : Effects of low blood pressure in cognitively impaired elderly patients treated with antihypertensive drugs. JAMA Intern Med 175 : 578-585, 2015. 